University of Nebraska - Lincoln DigitalCommons@University of Nebraska - Lincoln

USGS Staff -- Published Research

US Geological Survey

2013

\title{
A review of environmental impacts of salts from produced waters on aquatic resources
}

Aida M. Farag

U.S. Geological Survey, aida_farag@usgs.gov

David D. Harper

U.S. Geological Survey

Follow this and additional works at: http:// digitalcommons.unl.edu/usgsstaffpub

Part of the Geology Commons, Oceanography and Atmospheric Sciences and Meteorology Commons, Other Earth Sciences Commons, and the Other Environmental Sciences Commons

Farag, Aida M. and Harper, David D., "A review of environmental impacts of salts from produced waters on aquatic resources" (2013). USGS Staff -- Published Research. 916.

http://digitalcommons.unl.edu/usgsstaffpub/916

This Article is brought to you for free and open access by the US Geological Survey at DigitalCommons@University of Nebraska - Lincoln. It has been accepted for inclusion in USGS Staff -- Published Research by an authorized administrator of DigitalCommons@University of Nebraska - Lincoln. 


\title{
A review of environmental impacts of salts from produced waters on aquatic resources
}

\author{
Aïda M. Farag * , David D. Harper \\ U.S. Geological Survey, CERC - Jackson Field Research Station, Jackson, WY, USA
}

\section{A R T I C L E I N F O}

\section{Article history:}

Received 5 July 2013

Received in revised form 10 December 2013

Accepted 12 December 2013

Available online 21 December 2013

\section{Keywords:}

Water quality

Salt

$\mathrm{Cl}^{-}$

$\mathrm{HCO}_{3}^{-}$

Unconventional oil and gas

Coal bed natural gas

\begin{abstract}
A B S T R A C T
Salts are frequently a major constituent of waste waters produced during oil and gas production. These produced waters or brines must be treated and/or disposed and provide a daily challenge for operators and resource managers. Some elements of salts are regulated with water quality criteria established for the protection of aquatic wildlife, e.g. chloride $\left(\mathrm{Cl}^{-}\right)$, which has an acute standard of $860 \mathrm{mg} / \mathrm{L}$ and a chronic standard of $230 \mathrm{mg} / \mathrm{L}$. However, data for establishing such standards has only recently been studied for other components of produced water, such as bicarbonate $\left(\mathrm{HCO}_{3}^{-}\right)$, which has acute median lethal concentrations (LC50s) ranging from 699 to $>8000 \mathrm{mg} / \mathrm{L}$ and effects on chronic toxicity from 430 to $657 \mathrm{mg} / \mathrm{L}$. While $\mathrm{Cl}^{-}$is an ion of considerable importance in multiple geographical regions, knowledge about the effects of hardness (calcium and magnesium) on its toxicity and about mechanisms of toxicity is not well understood. A multiple-approach design that combines studies of both individuals and populations, conducted both in the laboratory and the field, was used to study toxic effects of bicarbonate (as $\mathrm{NaHCO}_{3}$ ). This approach allowed interpretations about mechanisms related to growth effects at the individual level that could affect populations in the wild. However, additional mechanistic data for $\mathrm{HCO}_{3}{ }^{-}$, related to the interactions of calcium $\left(\mathrm{Ca}^{2+}\right)$ precipitation at the microenvironment of the gill would dramatically increase the scientific knowledge base about how $\mathrm{NaHCO}_{3}$ might affect aquatic life. Studies of the effects of mixtures of multiple salts present in produced waters and more chronic effect studies would give a better picture of the overall potential toxicity of these ions. Organic constituents in hydraulic fracturing fluids, flowback waters, etc. are a concern because of their carcinogenic properties and this paper is not meant to minimize the importance of maintaining vigilance with respect to potential organic contamination.
\end{abstract}

Published by Elsevier B.V.

\section{Introduction}

Though the organic constituents used during the hydraulic fracturing process have been the subject of much public attention, the contribution of the salt content in large volumes of produced and flowback waters must also be addressed. Scientific data related to individual salts and mixtures would characterize their ecosystem effects independent of those that are specific and unique to hydrocarbons. To summarize the current state of knowledge, this paper will provide a summary of current issues related to the effects of salts, especially the ions chloride $\left(\mathrm{Cl}^{-}\right)$and bicarbonate $\left(\mathrm{HCO}_{3}^{-}\right)$, on aquatic resources.

The toxicity of salt from produced waters is not a new concept; research on its acute toxicity was investigated by Mount et al. (1997), who developed a model to define toxicity of various salts on a few aquatic species. Salt content (and related conductivity) of produced waters was the topic of a 2012 EPA workshop, and the acute and chronic toxicity of these salts is the focus of some USGS research studies

\footnotetext{
* Corresponding author at: P.O. Box 1089, Jackson, WY 83001, USA. Tel.: + 1307733 $2314 \times 11$.

E-mail address: aida_farag@usgs.gov (A.M. Farag).
}

(Farag and Harper, 2012). Some ionic components of produced waters are regulated with water quality criteria established for the protection of aquatic wildlife (e.g. $\mathrm{Cl}^{-}$), but data adequate for establishing such standards has only recently been studied for other elements (e.g. $\mathrm{HCO}_{3}^{-}$). Even when individual ions are regulated, additional issues arise due to total dissolved solids and salt absorption ratios (Farag et al., 2010).

Previous research determined that different ions (and salts they form) induce varying degrees of toxicity to aquatic life (Young, 1923; Rawson and Moore, 1944; Nelson, 1968; Mossier, 1971; Held and Peterka, 1974). Mount et al. (1997) completed more than a thousand acute experiments and developed a multiple regression model that described the toxicity of common ions in various combinations to zooplankton and fathead minnows (Pimephales promelas, FHM). One of the most pivotal findings of Mount et al. (1997) was that all major ions have a lethal concentration, and that the toxicity of a mixture of salts is generally equivalent to the additive toxicity of the individual salts.

Furthermore, data gaps exist in our understanding of the mechanisms by which salts affect individual organisms. The most prevalent theories include ionoregulatory upset with associated enzyme level changes. Understanding the mechanisms of toxicity becomes especially 
important when one attempts to interpret changes at the population level.

Multiple-approaches are needed to more completely define the potential toxicity of salt ions on aquatic life. Approaches should define the potential effects on individual organisms and populations and bridge laboratory and field studies, thereby enhancing the understanding of the potential effects of salts on aquatic resources (Fig. 1). It is the intersection of information as gathered from the individual organism with effects at the population level (moving left to right on Fig. 1), and the intersection of data gathered from the laboratory and the field (moving top to bottom on Fig. 1), that provide the ability to predict the overall effects of salts in real world conditions.

Studies that follow this multiple-approach design include: 1 . Acute and chronic laboratory experiments using water that mimics field conditions and provide data to determine no-effect level (NOEL) concentrations. 2. Investigations of the mechanisms of toxicity to allow interpretations of changes that can affect growth and ultimately survival. 3. Field surveys and in situ bioassays to ground truth laboratory data and refine information about lifestage sensitivity and potential population level effects. This multiple-approach type of study design should include experiments on multiple species as suggested for the development of water quality criteria to protect aquatic life (Stephan et al., 1985).

\section{Sodium chloride}

Sodium chloride $(\mathrm{NaCl})$ is a highly soluble naturally occurring salt commonly found with natural gas and oil reserves throughout the world. Most oil and gas deposits are the result of catagenesis and metagenesis of the residual marine-derived biogenic organic matter (Libes, 2009). Through complex geological processes, salt brines located within oil and gas producing strata can be highly concentrated, some much more concentrated than sea water (Thamke and Craigg, 1997; Iampen and Rostron, 2000; Whittemore, 2007). Most high salinity brines (>35 g/L TDS) contain chloride as their only major anion. To effectively remove oil or natural gas, water must be pumped out, or co-produced. Through the use of horizontal drilling and hydraulic fracturing, hydrocarbons can now be economically extracted in areas such as the Bakken Formation (North Dakota and Montana, northwestern USA, and Saskatchewan, western CA), the Barnett Shale (Texas, southcentral USA), and the Marcellus Shale (New York, Pennsylvania, Ohio, West Virginia and Virginia, eastern USA). However, the volume of $\mathrm{NaCl}$-enriched waters produced can exceed the amount of oil or gas over the lifespan of the well (Veil et al. 2004). A general ratio of brine to oil produced is 2:1 for conventional oil wells, however, Veil et al. (2004), reported that the volume of brine to oil increases over the life span of the well and produced water approached 10:1. This estimate

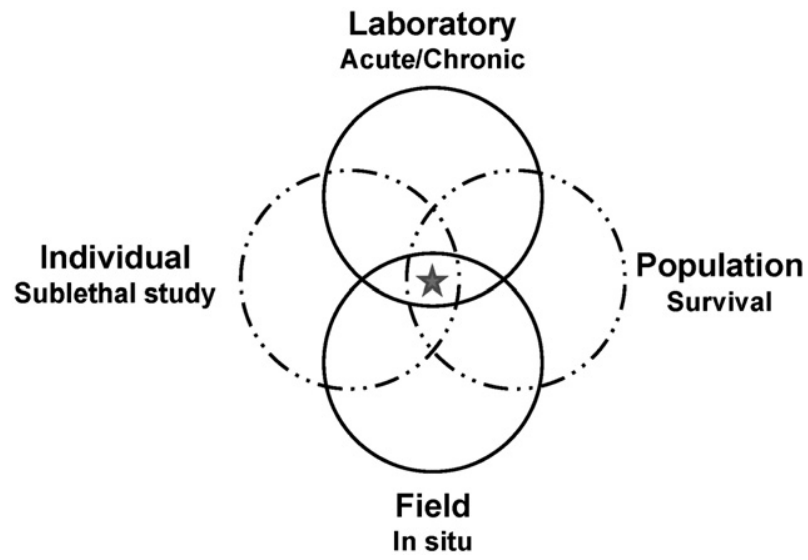

Fig. 1. A multiple- approach design needed to define the potential effects of salts at both the individual and population levels, and to move the understanding from the laboratory to the field. The star indicates where the data from the four approaches intersect to advance the state of knowledge. was made before the rapid increase in the use of horizontal drilling and hydraulic fracturing techniques which may delay or reduce water production (Veil et al., 2004), but may also increase total water production (Boysen, 2012). Regardless of the oil:water ratio, it is expected that increased oil production will require the construction of an additional 540 saltwater disposal sites before peak production in the early 2020 s in North Dakota alone (KLJ Consulting, 2012).

While $\mathrm{Cl}^{-}$is essential for biological function of aquatic organisms, large concentrations can disrupt ion balance. Freshwater aquatic organisms exist in a hypo-osmotic environment (internal dissolved solid concentrations are greater than the surrounding water) which requires the movement of ions to maintain ionic stasis against an osmotic gradient. This is accomplished, in part, by chloride cells, also called ionocytes or mitochondria-rich cells (Hobe et al., 1984; Perry, 1997). Chloride cells are found within membranes located in the gill or epithelium, and use energy to pump ions against an osmotic gradient (Wilson and Laurent, 2002). Chloride transfer mechanisms are also important in the movement of other ions into and out of aquatic organisms as required for biological function. When $\mathrm{Cl}^{-}$concentrations become large enough, they can interfere with ion regulation. While not well understood, it is believed that when concentrations become large enough, the ability to move $\mathrm{Cl}^{-}$and other ions becomes impaired, resulting in the inability to retain osmotic homeostasis and ionic balance.

Sodium chloride in produced water has been the subject of concern because of the potentially toxic effects of $\mathrm{Cl}^{-}$on aquatic organisms, and the physical alteration of soil structure that can occur when it is exposed to $\mathrm{Na}^{+}$. In an investigation of oil field discharge from conventional oil fields in Wyoming, Boelter et al. (1992) observed reduced survival and reproduction of Ceriodaphnia dubia. Major inorganic ions $\left(\mathrm{Na}^{+}\right.$, $\mathrm{K}^{+}, \mathrm{HCO}_{3}^{-}, \mathrm{Cl}^{-}$and $\mathrm{CO}_{3}^{2-}$ ) appeared to be the cause of toxicity, and trace metals and nonpolar organic compounds did not contribute to toxicity. In a study to predict the toxicity of major ions to aquatic organisms, Mount et al. (1997) found that C. dubia were quite sensitive to $\mathrm{NaCl}$ toxicity, with an acute $48 \mathrm{~h}$ median lethal concentration (LC50) of $1040 \mathrm{mg} / \mathrm{L}$. Toxicity was primarily attributed to the co-occurring anion of salts containing $\mathrm{Na}^{+}$and $\mathrm{Ca}^{2+}$. Thus, in produced waters containing predominantly $\mathrm{NaCl}$, most of the toxicity was attributed to $\mathrm{Cl}^{-}$. The USEPA water quality criterion established for the protection of aquatic life is $860 \mathrm{mg} / \mathrm{L}$ (U.S. Environmental Protection Agency, 1988) and is based on a series of experiments conducted on multiple species from various phyla.

Chronic toxicity to $\mathrm{Cl}^{-}$can occur at much lower concentrations than acute exposures. The USEPA established a chronic water quality criterion for $\mathrm{Cl}^{-}$of $230 \mathrm{mg} / \mathrm{L}$ in 1988 (U.S. Environmental Protection Agency, 1988). In a study of the effects of water hardness on $\mathrm{Cl}^{-}$toxicity, Elphick et al. (2011), found that increased availability of $\mathrm{Ca}^{2+}$ ions can ameliorate the toxic effects of $\mathrm{Cl}^{-}$. In this study, survival and reproduction of C. dubia were affected in concentrations as low as 132 and $117 \mathrm{mg} / \mathrm{L}$ $\mathrm{Cl}^{-}$respectively, in very soft water $\left(10 \mathrm{mg}\right.$ as $\left.\mathrm{CaCO}_{3}\right)$. However, survival and reproduction were strongly correlated with water hardness, indicating that water quality criterion may not be protective in soft waters less than $40 \mathrm{mg} \mathrm{CaCO}_{3} / \mathrm{L}$, and overly conservative in hard waters exceeding $100 \mathrm{mg} \mathrm{CaCO}_{3} / \mathrm{L}$.

As the potentially harmful effects of $\mathrm{Cl}^{-}$associated with oil and natural gas produced waters became better understood, disposal practices changed over time and have become more restricted and regulated. During early extraction activities, produced waters and brines were often pumped into un-lined evaporation reserve pits or simply pumped into receiving waters and drainage trenches (Gorman, 1999; Otton et al., 2005). The result of these disposal methods was often the contamination of ground and surface waters, salt scarring, erosion caused by the death of surface vegetation, and the dominance of salt tolerant organisms. Initial attempts to prevent leakage were through the use of lined evaporation reserve pits, but these were also prone to leakage. As of April 1, 2012, all waste waters associated with drilling and hydraulic fracturing activities in North Dakota must be stored in tanks. 
The long term movement and effects of $\mathrm{Cl}^{-}$entering ground and surface waters have been investigated in Williston Basin, located in the North Dakota, Montana, and South Dakota, northwestern USA, and Manitoba and Saskatchewan, western CA, a site of rapidly expanding oil production. This region is characterized by its unique prairie pothole landscape that is the major breeding area for waterfowl in North America (Gleason and Laubhan, 2008; Gleason et al. 2011). Brine concentration in produced waters from the Bakken Formation of the Williston Basin, where the most drilling activity is occurring, can exceed $450,000 \mathrm{ppm}$. The location of brine spills and leaking buried reserve pits has been known in the region, and these locations have been monitored periodically since at least the early 1980s (Beal et al., 1987; Murphy and Kehew, 1984). Brine from oil and gas production has a unique chemical signature (chloride and bromide) compared to the surrounding surface waters (bicarbonate and sulfate), which allows the source water to be distinguished (Reiten and Tischmak, 1993; Swanson et al., 2003). Migration of brine plumes in ground water is highly variable, but brine plumes are still found in proximity to but moving away from reserve pits created in the 1960s, indicating that the contamination is likely a long lived phenomenon. The long migration times connecting ground and surface waters make documenting the toxic effects of brine difficult; however, salt "burning" of aquatic plants and the replacement by salt tolerant, non-native species have been observed (Ray and Chesley-Preston, 2012).

Other researchers have found similar salt scarring, erosion, and ground and surface water contamination from production brines in Oklahoma and Kansas, southwestern and midwestern USA. At these sites, salt scarring, erosion caused by the death of ground covering vegetation, and a persistent elevation of chemically unique salt plumes can be found from oil and gas operations dating back to the mid-20th century (Otton et al., 2005).

\section{Sodium bicarbonate}

Though some debate exists about the current $\mathrm{Cl}^{-}$water quality criteria, they do provide a general point of reference for toxicity of waters that contain concentrations elevated above the criteria. But other ions do not have associated water quality criteria and the study of their toxicity is limited. To properly study additional salts, it is advantageous to use a location with a salt that is elevated in the absence of $\mathrm{Cl}^{-}$. Production water from the Powder River Structural Basin contains elevated concentrations of sodium bicarbonate $\left(\mathrm{NaHCO}_{3}\right)$, but not $\mathrm{Cl}^{-}$. The fate of water in this basin is often different from geographical regions with elevated $\mathrm{Cl}^{-}$because the coal seams tend to be within a few hundred meters of the surface and the quality of the water sometimes allows for beneficial use in stock ponds or for irrigation of arid crop and range lands (All Consulting, 2003; Benson et al., 2005). The salt content of these waters designated for beneficial use may affect soil integrity depending on the clay content and cause cracking of soils (Bauder, 2002) along with precipitation of salts (likely $\mathrm{Ca}^{2+}$ ) in riparian areas. Farag et al. (2010) provide a more extensive review of issues related to the beneficial use of untreated coal bed natural gas waters in the Powder River Structural Basin.

Historically, few published studies investigated the acute toxicity of $\mathrm{NaHCO}_{3}$ and field studies fell short of clearly demonstrating the effects of $\mathrm{NaHCO}_{3}$. Beatty (1959) experimented with rainbow trout (Oncorhynchus mykiss) and determined that $65 \%$ of the fish were killed within a week at a concentration of $1000 \mathrm{mg} \mathrm{NaHCO} / / \mathrm{L}$. However, Beatty (1959) used reconstituted water (distilled water plus $\mathrm{NaHCO}_{3}$ ) in the experiments, without the addition of other salts that are necessary for normal physiological functioning; the results, therefore, are not a reliable predictor of effects of this salt in natural waters. McCarraher and Thomas (1968) examined the tolerance of FHM in saline lakes in the sand hills of Nebraska, USA where $\mathrm{NaHCO}_{3}$ was the dominant salt. Using in situ bioassays, they determined that lakes in which the minnows were able to survive for 6 months or more had
$\mathrm{HCO}_{3}^{-}$and carbonate $\left(\mathrm{CO}_{3}^{2-}\right)$ concentrations that together averaged $1061 \mathrm{mg} / \mathrm{L}$. Galat et al. (1985) studied the Lahontan cutthroat trout (Oncorhynchus clarkii henshawi) in saline lakes in Nevada and Oregon, USA. This species is well known for its ability to tolerate saline conditions, an ability perhaps developed throughout the millennia from living in Pleistocene Lake Lahontan. Histological changes in the tissues of these fish were studied in lakes with a range of alkalinity from 60 to $3500 \mathrm{mg}$ $\mathrm{CaCO}_{3} / \mathrm{L}$. There was a correlation between $\mathrm{HCO}_{3}^{-}$, carbon dioxide $\left(\mathrm{CO}_{2}\right)$, $\mathrm{Cl}^{-}$concentrations and gill cell hyperplasia.

More recently, Farag and Harper (2012) conducted several types of experiments designed to fill the gap of knowledge about effect concentrations of $\mathrm{NaHCO}_{3}$, and the potential distribution of these effects in the Powder River Structural Basin as a sample watershed where $\mathrm{NaHCO}_{3}$ was elevated in the absence of $\mathrm{Cl}^{-}$. And the study design followed the multiple-approach design discussed above (Fig. 1). Acute and chronic studies completed in the laboratory included multiple species and phyla. A field survey and in situ bioassays were conducted to define the presence/absence of aquatic species, valuated laboratory data and refined information about lifestage sensitivity in field conditions. Experiments with mixing zone waters defined the extent of potential toxicity in the areas of concern. Finally, 60-d chronic exposure studies of selected fish species during their sensitive early life stages, examined the sublethal effects of $\mathrm{NaHCO}_{3}$ on growth, histology, whole-body ion concentrations and sodium-potassium adenosine triphosphatase ( $\mathrm{Na} / \mathrm{K}$ ATP-ase). These parameters provided a pattern of events to explain changes in growth and the results provided chronic no-effect levels.

Criteria often are established for single elements or ions, in this case most likely $\mathrm{HCO}_{3}^{-}$as the toxic fraction of the compound $\mathrm{NaHCO}_{3}$. Therefore, $\mathrm{HCO}_{3}^{-}$information was provided for use if derivations with this single element are preferred. Criteria could also be calculated as alkalinity because it is an easily measured water chemistry property that is expressed as $\mathrm{mg} \mathrm{CaCO}_{3} / \mathrm{L}$, but defines the amount of $\mathrm{HCO}_{3}^{-}$generally found in a sample with a $\mathrm{pH}<8.3$ (American Public Health Association Standard Methods, 1975).

Acute LC50s ranged from 989 to $>8000 \mathrm{mg} \mathrm{NaHCO} / \mathrm{L}$ (also defined as 699 to $>8000 \mathrm{mg} \mathrm{HCO}_{3}^{-} / \mathrm{L}$ or total alkalinity expressed as 608 to $>4181 \mathrm{mg} \mathrm{CaCO}_{3} / \mathrm{L}$ ) that varied across species and lifestage within a species. Ceriodaphnia dubia (C. dubia) results were similar to Mount et al. (1997) where the 48-h LC50 was $1020 \mathrm{mg} \mathrm{NaHCO} / \mathrm{L}$ compared to $1288 \mathrm{mg} \mathrm{NaHCO} / \mathrm{L}$ observed during this study (both completed in moderately hard reconstituted water). Therefore, data from the Farag and Harper (2012) studies are comparable to the limited amount of data in the literature and can be broadly applied because effects are defined on a wide range of species.

For chronic toxicity experiments, sublethal effects such as growth and reproduction, in addition to significant reductions in survival, were included in the final determination of effects. Chronic toxicity was observed at concentrations that ranged from 450 to $800 \mathrm{mg}$


expressed as 354 to $539 \mathrm{mg} \mathrm{CaCO} / \mathrm{L}$ ) and the specific concentration depended on the sensitivity of the four species of invertebrates and fish exposed.

A combination of the percent decrease in the activity of $\mathrm{Na} / \mathrm{K}$ ATPase and the age of the fish at the onset of the decrease may affect the ability of FHM to survive. Fish were able to survive a decrease in $\mathrm{Na} / \mathrm{K}$ ATPase activity in the $400 \mathrm{mg} \mathrm{NaHCO} / \mathrm{L}$ treatment when this decrease was first documented on day 60 . However, fish with a similar decrease in $\mathrm{Na} / \mathrm{K}$ ATPase activity first documented on day 37 in the $500 \mathrm{mg}$ $\mathrm{NaHCO}_{3} / \mathrm{L}$ treatment incurred significant reductions in survival, and survivors subsequently exhibited a much greater reduction in $\mathrm{Na} / \mathrm{K}$ ATPase at day 60.

Field experiments at multiple tributary sites resulted in reduced survival. Concentrations of $\mathrm{NaHCO}_{3}$ at these sites were above $\mathrm{LC}_{5} \mathrm{~S}_{\mathrm{s}}$ defined in the laboratory, and the same species were used in laboratory and field experiments. Trace element analyses of water collected from the field 
did not reveal any other potential cause for the toxicity. Measurements for trace organic constituents were not performed.

The mixing zone study provided evidence of substantial mixing near the outfalls to the main stem (800-1200 m below the confluence) and also demonstrated a reduction in toxicity (based on survival) of water that was treated with ion exchange (Higgins Loop) before release into the Tongue River. These experiments addressed the toxicity of effluent waters being added to and diluted in relatively large rivers, but did not address issues related to the volumes of water that may be added to the watershed or the cumulative effects of coal bed natural gas discharge in the Powder River Structural Basin, USA.

Data from the field experiments also defined a difference in sensitivity with age of the early lifestage fish. FHM aged 2-day-post-hatch (dph) were significantly more sensitive than 6-dph FHM. As a result, care should be taken when extrapolating results from experiments with older than 2-dph, to younger fish that seem to be more sensitive to $\mathrm{NaHCO}_{3}$. Using older FHM will likely result in under predicting the toxic effects of salts. It is possible that a decrease in $\mathrm{Na} / \mathrm{K}$ ATPase (though not measured here) may have affected the ability of the 2-dph fish to survive in the field.

\section{Summary and overview}

Treating and/or disposing of salts contained in produced waters provide a daily challenge for operators and resource managers. There are few closed loop systems for water use. The constant transport of these waters to treatment and disposal locations increases the likelihood of spills during transport, and the volume of production increases the likelihood of spills at the well. Accidental releases can result in detrimental effects on aquatic life (Papoulias and Velasco, 2013). While large spills cause dramatic effects such as fish kills, small releases may contribute to cumulative changes in the overall salt composition and aquatic community structure. The volume of water generated along with the elevated salt content and corresponding total dissolved solids (TDS) contained in the waters make treatment at municipal waste water treatment facilities less effective. Therefore, operators must look for alternative treatment and disposal options.

Though specific guidelines are established by individual states, $98 \%$ of brines are currently re-injected into deep aquifers (where seismically appropriate) for disposal when TDS concentrations are greater than $2500 \mathrm{mg} / \mathrm{L}$, or used for water-flooding to enhance oil recovery (Benson et al., 2005; Clark and Veil, 2009; Rice and Nuccio, 2000). The remaining $2 \%$ of brines is disposed of in a variety of other ways including beneficial use (Clark and Veil, 2009). Reserve pits used to hold produced water and waters used during the hydraulic fracturing process have been replaced by storage tanks, with brines and production waters trucked or piped to reinjection or water treatment sites. These methods will minimize the potential for brines and produced waters to enter ground and surface water. However, because of the rapid pace of drilling occurring in areas such as the Williston Basin, and the Marcellus Shale, infrastructure and the ability to track the fate of produced waters and brines have not kept pace with oil and gas activities.

Data exists to define the toxicity to aquatic biota of $\mathrm{Cl}^{-}$and $\mathrm{HCO}_{3}^{-}$, two ions that are prominent in waters associated with oil and gas production. But to advance the science and properly inform operators and managers about the effects of salts on aquatic life, the science of salt toxicity must mature. Currently, one of the few ions associated with produced waters with an established water quality criterion is $\mathrm{Cl}^{-}$. While it is an ion of considerable importance in multiple geographical regions, knowledge about the effects of hardness on its toxicity and about mechanisms of toxicity is not well understood. The study of $\mathrm{HCO}_{3}^{-}$is relatively young and the results should be repeated and verified by others, and investigations of mechanisms should be expanded. For example, as the concentrations of $\mathrm{HCO}_{3}^{-}$increase, $\mathrm{Ca}^{2+}$ decreases and appears to precipitate. The interactions of this process at the microenvironment of the gill would dramatically increase the scientific knowledge base about how $\mathrm{HCO}_{3}^{-}$might affect aquatic life, and thus populations, in the wild. Mount et al. (1997) suggested that the toxicity of salts was additive and their resulting model has wide applicability. However, those experiments were conducted with a limited number of species and only encompassed acute effects. Toxicity studies with mixtures of salts present in produced waters and more chronic effect studies would give a better picture of the overall potential toxicity of these ions.

\section{Acknowledgement}

Any use of trade, product, or firm names is for descriptive purposes only and does not imply endorsement by the U.S. Government. The authors thank the Science Team about Energy and Prairie Pothole Environments (STEPPE) and John Powell Center for Analysis and Synthesis for providing information about multiple formations. Funding for this review was provided by U.S. Geological Survey.

\section{References}

All Consulting, 2003. Handbook on Coal Bed Methane Produced Water: Management and Beneficial Use Alternatives: Coal Bed Natural Gas Resources and Produced Water Management ([http://www.all-llc.com/CBNG/BU/index.htm] accessed April 2012).

American Public Health Association Standard Methods, 1975. Alkalinity Titration Method for Water and Wastewater (14th ed.), 14th ed. American Public Health Association, Washington, D.C. 278.

Bauder, J.W., 2002. Quality and characteristics of saline and sodic water affect irrigation suitability: Montana State University. accessed April 10, 2010 at http:// waterquality.montana.edu/ (7 p.).

Beal, W.A., Murphy, E.C., Kehew, A.E., 1987. Migration of contaminants from buried oiland-gas drilling fluids within the glacial sediments of north-central North Dakota. N. Dakota Geol. Surv. Rep. Inv. No. 86, 43.

Beatty, D.D. 1959. An Experimental Study of the Toxicity of Sodium Bicarbonate, Sodium Chloride, and Sodium Sulfate to Rainbow Trout. M.S., University of Wyoming, Laramie, Wyoming 69 p.

Benson, M., Bergman, H., Boelter, A., Coupal, R., Hoffer, N., Hulme, D., Korfanta, N., Lieske, S., Lovato, J., Miller, S., Munn, L., Reddy, K., 2005. Water Production from Coalbed Methane Development in Wyoming: A Summary of Quantity, Quality and Management Options--Final Report. University of Wyoming, Laramie, WY 64 p.

Boelter, A.M., Lamming, F.N., Farag, A.M., Bergman, H.L., 1992. Environmental effects of saline oil-field discharges on surface waters. Environ. Toxicol. Chem. 11, 1187-1195.

Boysen, J, 2012. The impact of horizontal drilling for natural gas on produced water management strategies. International Petroleum Environmental Conference, Denver CO (http://ipec.utulsa.edu/Conf2012/Papers_Presentations/Boysen_Plenary_Rev.pdf, accessed October 18, 2013).

Clark, C.E., Veil, J.A., 2009. Produced Water Volumes and Management Practices in the United States. Argonne National Laboratory, Argonne, Illinois 1-64.

Elphick, J.R.F., Bergh, K.D., Bailey, H.C., 2011. Chronic toxicity of chloride to freshwater species: effects of hardness and implications for water quality guidelines. Environ. Toxicol. Chem. 30, 239-246.

Farag, A.M., Harper, D.D., Senecal, A., Hubert, W.A., 2010. Chapter \#11 Potential Effects of Coal Bed Natural Gas Development on Fish and Aquatic Resources. (Invited) In: Reddy, K.J. (Ed.), Coalbed Natural Gas: Energy and Environment. Nova Science Publishers, Hauppauge, New York, pp. 227-242.

Farag, A.M., Harper, D.D. (Eds.), 2012. The potential effects of sodium bicarbonate, a major constituent from coalbed natural gas production, on aquatic life. US Geol. Surv. Sci. Investig. Rep. 2012-5008, 101.

Galat, D.L., Post, G., Keefe, T.J., Bouck, G.R., 1985. Histological changes in the gill, kidney and liver of Lahontan cutthroat trout, Salmo clarki henshawi, living in lakes of different salinity-alkalinity. J. Fish Biol. 27, 533-552.

Gleason, R.A., Laubhan, M.K., 2008. Background and approach to quantification of ecosystem services. In: Gleason, R.A., Laubhan, M.K., Euliss Jr., N.H. (Eds.), Ecosystem Services Derived From Wetland Conservation Practices in the United States Prairie Pothole Region with an Emphasis on the U.S. Department of Agriculture Conservation Reserve and Wetlands Reserve Programs, 1745. U.S. Geological Survey Professional Paper, pp. 3-14.

Gleason, R.A., Euliss Jr., N.H., Tangen, B.A., Laubhan, M.K., Browne, B.A., 2011. USDA conservation program and practice effects on wetland ecosystem services in the Prairie Pothole Region: ecological applications. Suppl. vol. 21, S65-S81.

Gorman, H.S., 1999. Efficiency, Environmental Quality, and Oil Field Brines: The Success and Failure of Pollution Control by Self-regulation: Business History Review, vol. 73 601-640.

Held, J.W., Peterka, J.J., 1974. Age, growth, and food habits of the fathead minnow Pimephales promelas, in North Dakota saline lakes. Trans. Am. Fish. Soc. 103, 743-756.

Hobe, H., Wood, C.M., McMahon, B., 1984. Mechanisms of acid/base and ionoregulation in white suckers Catostomus commersoni in natural soft water. J. Comp. Physiol. 154, 35-46.

Iampen, H.T., Rostron, B.J., 2000. Hydrogeochemistry of pre-Mississippian brines, Williston Basin, Canada-USA. J. Geochem. Explor. 69-70, 29-35

KLJ Consulting, 2012. Power forecast, 2012: Williston Basin Oil and gas related electrical load growth forecast. http://www.nd.gov/ndic/ic-press/Power2012.pdf (accessed, October 18, 2013). 
Libes, S.M., 2009. Introduction to Marine Biogeochemistry. Elsevier press 928.

McCarraher, D.B., Thomas, R., 1968. Some ecological observations on the fathead minnow, Pimephales promelas, in the alkaline waters of Nebraska. Trans. Am. Fish. Soc. 97 52-55.

Mossier, J.N., 1971. The Effect of Salinity on the Eggs and Sac Fry of the Fathead Minnow (Pimephales promelas promelas), Northern Pike (Esox lucius) and Walleye (Stizostedion vitreum vitreum). North Dakota State University, Fargo, North Dakota 47 (Ph.D dissertation).

Murphy, E.C., Kehew, A.E., 1984. The effect of oil and gas well drilling fluids on shallow groundwater in western North Dakota. N. Dakota Geol. Surv. Rep. Inv. No. 82, 156.

Mount, D.R., Gulley, D.D., Hockett, J.R., Garrison, T.D., Evans, J.M., 1997. Statistical model to predict the toxicity of major ions to Ceriodaphnia dubia, Daphnia magna, and Pimephales promelas (fathead minnows). Environ. Toxicol. Chem. 16, 2009-2019.

Nelson, J.S., 1968. Salinity tolerance of brook sticklebacks, Culaea inconstans, freshwater ninespine sticklebacks, Pungitius pungitius, and freshwater fourspine sticklebacks, Apeltes quadracus. Can. J. Zool. 46, 663-667.

Otton, J.K., Zielinski, R.A., Smith, B.D., Abbott, M.M., Keeland, B.D., 2005. Environmenta Impacts of Oil Production on Soil, Bedrock, and Vegetation at the U.S. Geological Survey Osage-Skiatook Petroleum Environmental Research site A, Osage County, Oklahoma (Nielsen, D.L., Brock, M.A., Rees, G.).

Papoulias, D.M., Velasco, J.L., 2013. Histolpathological Analysis of Fish from Acorn Creek, Kentucky, Exposed to Hydraulic Fracturing Fluid Releases Southeast. Nat. 12(4):92-111.

Perry, S.F., 1997. The chloride cell: structure and function in the gills of freshwater fishes. Annu. Rev. Physiol. vol. 59, 325-347.

Rawson, D.S., Moore, J.E., 1944. The saline lakes of Saskatchewan. Can. J. Res. 22, 141-201

Ray, A., Chesley-Preston, T., 2012. Brine contamination to aquatic resources in the PrariePothole region and Williston Basin. USGS http://steppe.cr.usgs.gov/pdf/EPA PPBrineTalk_30may12_Final.pdf (accessed July 3, 2013).
Reiten, J.C., Tischmak, T., 1993. Appraisal of Oil Field Brine Contamination in Shallow Ground Water and Surface Water, Eastern Sheridan County. Open-File , 260. Montana Bureau of Mines and Geology, Montana Billings, Mont 296 (2 sheet(s)).

Rice, C.A., Nuccio, V.F., 2000. Water produced with coal bed methane. U.S. Geological Survey Fact Sheet FS-156-00. http://pubs.usgs.gov/fs/fs-0156-00/ (accessed May 2013).

Stephan, C.E., Mount, D.I., Hansen, D.J., Gentile, J.R., Chapman, G.A., Brungs, W.A., 1985. Guidelines for Deriving Numerical National Water Quality Criteria for the Protection of Aquatic Organisms and Their Uses. U.S. Environmental Protection Agency, Office of Research and Development, Duluth 106 (EPA-PB85-227049).

Swanson, G.A., Euliss Jr., N.H., Hanson, B.A., Mushet, D.M., 2003. Dynamics of a prairie pothole wetland complex-implications for wetland management, in Winter, T.C., ed., hydrological, chemical, and biological characteristics of a Prairie Pothole Wetland Complex under highly variable climate conditions - the Cottonwood Lake Area, East-Central North Dakota. U. S. Geol. Surv. Prof. Pap. 1675, 55-94.

Thamke, J.N. Craigg S.D. 1997. Saline-water contamination in Quaternary deposits and the Poplar River, East Poplar oil field, northeastern Montana. U.S. Geological Survey Water-resources Investigations Report, 97-4000, p. 37.

U.S. Environmental Protection Agency, 1988. Ambient Water Quality Criteria for Chloride. Environmental Monitoring Systems Laboratory Office of Research and Development. U.S. Environmental Protection Agency, Cincinnati 39 (EPA 440/5-88-001).

Veil, J.A., Puder, M.G., Elcock, D., Redweik Jr., R.J., 2004. A White Paper Describing Produced Water From Production of Crude Oil, Natural Gas, and Coal Bed Methane: Prepared for the U.S. Department of Energy, National Energy Technology Laboratory. Argonne National Laboratory, Argonne, Ill 79.

Whittemore, D.O., 2007. Fate and identification of oil-brine contamination in different hydrogeologic settings: Applied Geochemistry 22 (10), 2099-2114.

Wilson, J.M., Laurent, P., 2002. Fish gill morphology: inside out. J. Exp. Zool. 293, 192-213.

Young, R.T., 1923. Resistance of fish to salts and alkalinity. Am. J. Physiol. 63, 373-388. 